Наносистели, нанолатеріали, нанотехнології Nanosistemi, Nanomateriali, Nanotehnologii 2020 , т. 18, № 3, сc. 541-550 (c) 2020 IМФ (Інститут металофізики ім. Г. В. Курдюмова НАН України) Надруковано в Україні. Фотокопіювання дозволено тільки відповідно до ліцензії

PACS numbers: 05.65.+b, 82.37.Np, 82.39.Fk, 82.65.+r, 87.14.ej, 87.15.A-, 87.15.R-

\title{
Notes to the Centenary of Michaelis-Menten's Scheme
}

\author{
L. N. Christophorov
}

Bogolyubov Institute for Theoretical Physics, N.A.S. of Ukraine, 14 , Metrologichna Str., UA-03143 Kyiv, Ukraine

The Michaelis-Menten's (MM) scheme serves as a basis for enzymatic kinetics rather long since. Early attempts to search for internal mechanisms of regulation of enzyme activity rooted in the conformational lability and for corresponding deviations from the classical kinetics were practically ignored for a prolonged period. Nowadays, however, there is no lack of theoretical papers devoted to various MM-like schemes. This is mainly conditioned by implementation of the single-molecule (SM) methods into enzymology, and by similarities to heterogeneous (nano)catalysis with its direct analogue to the MM scheme called Langmuir-Hinshelwood's model. It is expedient to assess the interim achievements on this way. With this purpose, the most basic example, namely, reactions of monomeric enzymes with an only binding site, is considered. In this generic case, it is especially clear, which new possibilities arise due to conformational fluctuations of the enzyme and how transparent is their physical nature. The minimal MM-like schemes, which exhaust all the characteristic regulation phenomena caused by the presence of conformational channels (non-monotonic dependence of the velocity on the rate of substrate release, cooperativity, and substrate inhibition), are described. An alternative approach based on our previously proposed concept of molecular self-organization to the enzyme functioning along the lines of nonequilibrium phase transitions is outlined.

Схема Міхаеліса-Ментен (MМ) достатньо давно служить основою для ферментативної кінетики. Ранні спроби пошуку внутрішніх механізмів регуляції активности ферментів, що кореняться в їхній конформаційній лабільності, та відповідних відхилень від класичної кінетики були практично ігноровані протягом тривалого періоду. Однак сьогодні не бракує теоретичних робіт, присвячених різноманітним ММ-подібним схемам. Це, здебільшого, зумовлено впровадженням в ензимологію метод досліджень на рівні поодиноких молекул, а також подібностями до гетерогенної (нано)каталізи, де модель Ленгмюра-Гіншелвуда є прямим аналогом ММсхеми. Доцільно оцінити проміжні здобутки в цьому напрямі. 3 цією ме- 
тою розглядається найосновніший приклад - реакції мономерних ферментів з єдиним місцем зв'язування. У цьому наріжному випадку особливо ясно, які нові можливості виникають внаслідок конформаційних флюктуацій ферменту і наскільки прозорою є їхня фізична природа. Описано мінімальні ММ-подібні схеми, які вичерпують всі характерні явища регуляціï, спричинені наявністю конформаційних каналів (немонотонна залежність швидкости від швидкости вивільнення субстрату, кооперативність та субстратне інгібування). Окреслено альтернативний підхід до функціонування ферментів в термінах нерівноважних фазових переходів, заснований на запропонованій нами раніше концепції молекулярної самоорганізації.

Key words: enzymatic reactions, Michaelis-Menten's schemes, monomeric enzymes, conformational regulation, reaction velocity.

Ключові слова: ферментативні реакції, схеми Міхаеліса-Ментен, мономерні ферменти, конформаційна регуляція, швидкість реакції.

(Received 3 December, 2019)

\section{INTRODUCTION}

Enzymes are very complex biomacromolecules. Nevertheless, the methods of standard chemical kinetics based on the mass action law still dominate the description of enzymatic reactions. This approach is rooted in the historic work [1], with its centenary been widely celebrated [2]. The kinetic scheme proposed in [1] remains a starting point for studying any enzyme and proves its ubiquity in many other fields, including nanocatalysis [3, 4]. After the advent of single molecule (SM) enzymology [5], the number of works on the validity of the MichaelisMenten's (MM) scheme and its generalizations is permanently growing. It seems expedient to look closer at the results of this activity and to foresee its further development. The general trend can be traced with the pivotal example, precisely, reactions of a monomeric enzyme with an only binding site. Also, an alternative approach to the mechanisms of enzyme functioning is proposed.

\section{THE CLASSIC MM SCHEME AND ITS SM VERSION}

The kinetic MM scheme implies conversion of substrate $S$ to product $P$ by enzyme $E$ through the stage of reversible substrate binding with formation of the enzyme-substrate complex $E S$, and subsequent catalytic stage of releasing the product and free enzyme capable of performing the next identical turnover. In its original form, it reads

$$
E+S \underset{b}{\stackrel{a}{\rightleftarrows}} E S \stackrel{r}{\longrightarrow} E+P
$$


with the corresponding kinetic equation

$$
d[E S] / d t=-(b+r)[E S]+a[E]
$$

added with the condition of conservation of the total enzyme concentration: $\left[E_{T}\right]=[E]+[E S]$. Here, $a, b$ and $r$ are rate constants of reactions at the stage of binding, unbinding and product release, respectively. As a rule, substrate concentration $[S]$ is supposed to be maintained constant, so the rate constant $a$ is proportional to [S], $a=k_{1}[S]$, and kinetics becomes linear. The prime characteristic of an enzymatic reaction is the velocity of product formation, $v=d P / d t=r[E S]$. In the stationary case, Eq. (2) immediately yields

$$
v=r\left[E_{t}\right][S] /\left([S]+K_{M}\right),
$$

where $K_{M}=(b+r) / k_{1}$ is Michaelis constant. The hyperbolic dependence $v([S])(3)$ is the main result of scheme (1) and primary test for studying any enzymatic reaction. For many years, its universality was not called into question. In mid-1960's, however, the problem of regulation of such reactions, in the first place, by means of modification of the $v([S])$ dependence to a more pronounced one than that in Eq. (3), came to the fore. At those times, it was already known about 'cooperativity' of binding oxygen by haemoglobin, with its 'sigmoid' (i.e., trigger-like) saturation curve, as distinct from hyperbolic for myoglobin. Haemoglobin differs from the latter in its oligomeric structure (consists of four sub-units, each with its own binding site). Consequently, the first kinetic models of cooperativity contained several active centres, too. In addition, however, it seemed obligatory to introduce different conformational states of sub-units [6]. And that has turned out to be a decisive step, since (as it was firstly noted in one-paged paper [7]) cooperativity could be imitated even by a monomeric enzyme with a single binding site, if only to suggest (i) the presence of two conformations, $E_{1}$ and $E_{2}$, of free enzyme, differing in affinity to the substrate, and (ii) a slow conformational transition between $E_{2}$ and $E_{1}$. For a prolonged period, this idea was beyond the mainstream, and the MM-scheme position with respect to monomeric enzymes remained firm until the first single enzyme experiments.

The latter make it possible to obtain stochastic 'trajectories' of durations of the enzyme residence in particular reaction states. Statistical processing of such trajectories yields, in particular, the probability distribution function $f(t)$ of the 'first passage time', i.e., the time from the beginning of substrate binding to the product release. Then, modelling scheme (1) is based on equations for probabilities $P_{E}(t), P_{E S}(t)$ instead of concentrations $[E],[E S]$ :

$$
d P_{E} / d t=-a P_{E}+b P_{E S}, d P_{E S} / d t=a P_{E}-(b+r) P_{E S}
$$


with initial conditions $P_{E}(0)=1, P_{E S}(0)=0$. It should be stressed that the first equation of set (4), as distinct from Eq. (2), does not contain (because of the very sense of $f(t)$ ) the term $r P_{E S}$ of the enzyme return to its free state, so that the condition $P_{E}(t)+P_{E S}(t)=1$ holds for $t=0$ only. ${ }^{1}$ Obviously, $f(t)=r P_{E S}(t)$, and easy solving set (4) and calculating the mean first passage time $\langle t\rangle=\int_{0}^{\infty} t f(t) d t$ yield

$$
1 /\langle t\rangle=r a /(a+b+r) .
$$

Comparing Eq. (5) with Eq. (3) and remembering that $a=k_{1}[S]$, one can see their identity, that is, $v /\left[E_{T}\right]=1 /\langle t\rangle$ (so called single molecule Michaelis-Menten's equation [8]).

Although its validity has been proved experimentally for a particular enzyme [9], even the first data of SM spectroscopy of enzymatic reactions showed considerable deviations of the dwell time distributions and corresponding correlation functions from exponential ones [5]. That was not consistent with the classic MM scheme. Yet, despite a much higher level of experiment, to explain these data, the same linear kinetics is still applied to various versions of the MM scheme split into several conformational channels. Currently, this is the main trend of numerous papers ([8-14], to cite a few), often overloaded with bulky linear algebra or unnecessary, too sophisticated (sometimes, even contradictory) substantiations of kinetic equations. Meanwhile, all principal effects of deviations from MM's behaviour can be illustrated with minimal two-channel schemes (Fig. 1). Actually, there are three such effects.

\section{EFFECTS OF CONFORMATIONAL SPLITTING}

Scheme in Fig. 1, $a$ proposed in [15] illustrates a counter-intuitive effect of a non-monotonic dependence of the reaction velocity on rate constant $b$ of 'unproductive' substrate unbinding, provided that catalytic rate constants $R$ and $r$ in the channels are markedly different. Here, the possibility of the enzyme return from less active state $E S_{2}$ to initial state $E$ with a chance to proceed via more active state $E S_{1}$ may not slow down but accelerate the catalysis (see Fig. $2, a$ ). It is easy to derive a relationship between $[S]$ and difference $(R-r)$ necessary for the effect (first noted 100 years after introduction of the MM scheme).

Scheme in Fig. 1, $b$ was proposed in [16] as a simplified version of Rabin's scheme [7] of cooperativity of a monomeric enzyme. The effect

\footnotetext{
${ }^{1}$ This is often ignored in current literature, leading to confusions in derivations.
} 
requires the presence of two conformational states of the free enzyme, with one of them $\left(E_{1}\right)$ being more stable while the other $\left(E_{2}\right)$ having better affinity $(A>a)$. If the conformational transition $E_{2} \rightarrow E_{1}$ is slow, then, with $[S]$ increasing, the enzyme stays longer in more active state $E_{2}$, having no time to relax to $E_{1}$ before the next substrate arrives. It is the physical reason that initiates cooperativity (flexion of curve $v([S])$, as distinct from MM's hyperbola), so smartly captured by Rabin. True, in models with discrete conformation, this flexion shows up rather poorly (see an example in Fig. $2, b$ ) due to algebraic structure of the dependence $v([S])$, which implies a ratio of two polynomials of rather low power.

Scheme in Fig. 1, $c$, apart from the possibilities of the two previous schemes, also includes the substrate inhibition effect. The latter shows up, if catalytic rates $R$ and $r$ are markedly different. At certain values of the scheme parameters, the role of the less active channel can grow with $[S]$ increasing. This suppresses the cooperativity effect (see Fig. $2, c$ for an example).

All further extensions of such schemes (like increasing the number of channels or intermediate states) do not reveal any new effects of conformational regulation and only complicate the analysis by introducing too many parameters which could never be determined experimentally. Resuming this still dominant trend, we note the following.

The MM-like schemes with discrete conformation channels analysed within linear equations with constant coefficients can be helpful in qualitative elucidation of conformational regulation, at least as long as they are kept simple. Indeed, deriving the reaction velocity from stationary solutions of Eq. (2)-like equations is trivial. Not much harder is finding the mean first passage time $\langle t\rangle$ in SM-versions where $1 /\langle t\rangle$ plays the reaction velocity role. In these cases, it is sufficient to solve the corresponding non-stationary problem like (4) in Laplace transforms only ${ }^{2}$, since all the moments $\left\langle t^{m}\right\rangle$ can be found simply as $\left\langle t^{m}\right\rangle=(-1)^{m} d \tilde{f}(s) /\left.d s\right|_{s=0}$.

As the SM MM equation $v /\left[E_{T}\right]=1 /\langle t\rangle$ remains valid in the presence of different conformational channels, the SM versions do not reveal any principally new regulation mechanisms except the mentioned above, derived in ensemble versions. Overall, the whole trend seems methodologically exhausted, since attempts to refresh it by the SM approach would be most likely reduced to re-discovering the already known effects in more complicated and even contradictory ways, as it currently takes place.

In addition, the discrete schemes have inherent limitations not consistent with real protein reaction kinetics: the rate 'constants' are in

\footnotetext{
${ }^{2}$ Of course, the initial population distribution $P_{E_{i}}(0)$ should be imposed correctly, i.e., proportionally to stationary restoring fluxes $r_{i}\left[E S_{i}^{s t}\right]$ to these sub-states within the channels.
} 

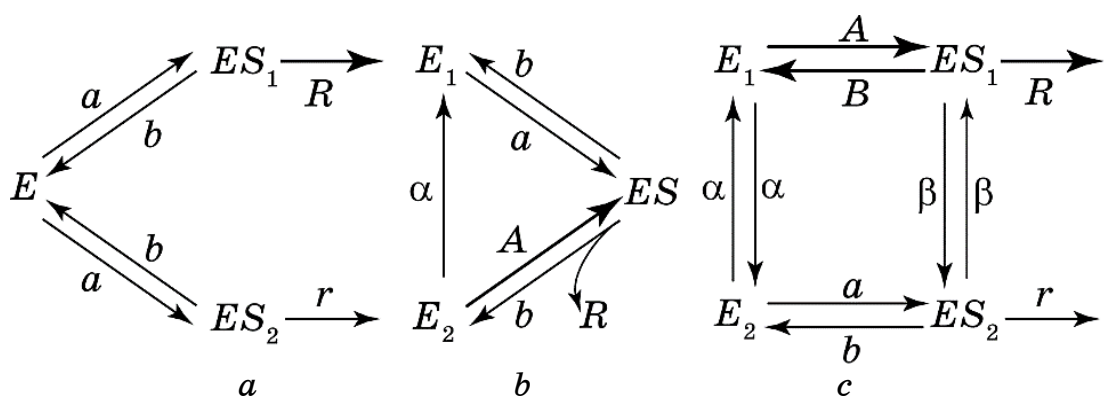

Fig. 1. Generic schemes for the effects caused by introducing different conformational channels into the classical MM scheme (see the text).
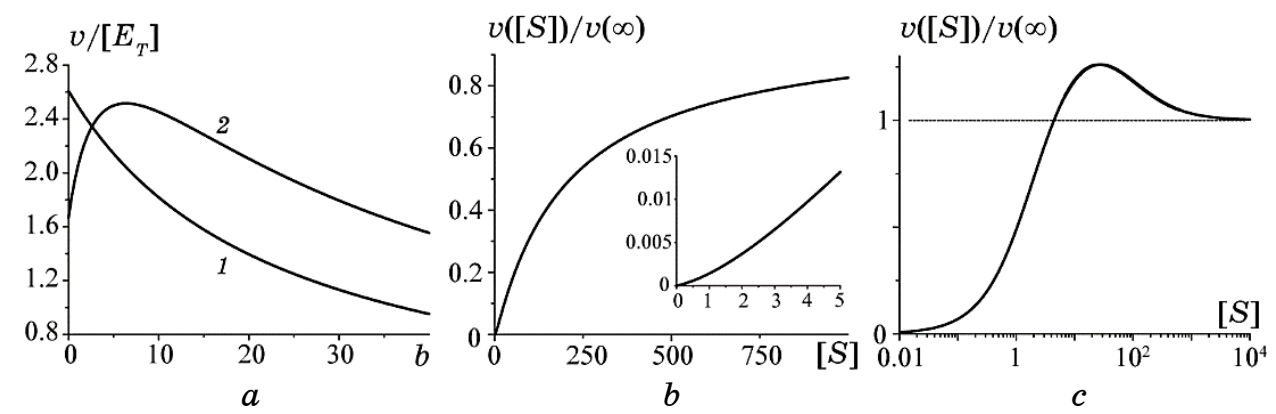

Fig. 2. (a) Non-monotonic $v(b)$ in the scheme in Fig. 1, $a . a=10$. Curve 1: $R=r=3$; curve $2: R=10, r=1$. (b) Weak cooperativity in the scheme in Fig. 1 , $b$ with the return after the catalytic stage to sub-state $E_{2}$. The flexion of $v([S])$ is negligible unless one looks at the concave in the inset for extremely small $[S]$. Here, $\alpha=1, k_{1}=a /[S]=0.1, k_{2}=A /[S]=1, b=10, R=100$. (c) Substrate inhibition in the scheme in Fig. $1, c . \alpha=10, \beta=1 k_{1}=A /[S]=10, k_{2}=A /[S]=$ $=1, b=10, B=1, r=1, R=10$.

fact rarely constant and can influence each other, the kinetics is often essentially non-exponential, etc. The approach presented in the next section avoids these limitations and provides a new insight into formation of functional regimes of enzymatic reactions.

\section{SELF-ORGANIZING REGIMES}

Actually, they follow from quite natural considerations on substrateconformational interactions [17-19]. Let us suppose that the enzyme structure changes caused by substrate binding/unbinding are characterized by generalized structural coordinate $x$ with its dynamics being much slower than that of the changes in reaction states. Let structural potentials $V_{0}(x), V_{1}(x)$ correspond to states $E, E S$, respectively. The 
strength of substrate-conformational interaction can be characterized, for example, by shift $x_{m}$ of the potential minimum position, like $V_{0}(x)=(\gamma / 2) x^{2}$ and $V_{1}(x)=(\gamma / 2)\left(x-x_{m}\right)^{2}$ for harmonic potentials. Obviously, the rate constants of Scheme (1) become dependent on $x$. In turn, dynamics of the latter is determined by dichotomous switching of force $F_{t}$ between its values $-V_{0}^{\prime}(x),-V_{1}^{\prime}(x)$. The master equation for probabilities $\rho_{0,1}(t \mid x)$ of realization of these values has the form of a balance equation with $x$-dependent rates, thereby ensuring the feedback and nonlinearity in the system.

Formulated in such a way, the stochastic problem added with a thermal white noise can be reduced to a Fokker-Planck equation for structural distribution function $P(x, t)$ with effective potential $V^{e f f}(x)$, and the shape of the latter is determined by $x$-dependent rates. For them, the following assumption frequently used in kinetics of biochemical reactions can be adopted: $a=k_{1}[S], k_{1} / b=\exp \left(-\Delta G /\left(k_{B} T\right)\right)$, where $\Delta G$ is the free energy lowering (increase in affinity) due to structural fit to the substrate. The quantity $-\Delta G /\left(k_{B} T\right)$ can be taken as a generalized structural coordinate. Then, $x$-dependent Michaelis' constant $K_{M}(x)=b(x) / k_{1}+r(x) / k_{1}$, which enters the $V^{e f f}$-defining equation

$$
d V^{e f f} / d x=d V_{0} / d x+\left(d V_{1} / d x-d V_{0} / d x\right)[S] /\left([S]+K_{M}(x)\right),(6)
$$

is simply $K_{M}(x) \approx \exp (-x)$, if $r(x) \ll b(x)$. Analysis shows [20] that, with [S] growing from 0 to $\infty$, the effective potential, changing from $V_{0}(x)$ to $V_{1}(x)$, under sufficient strength of substrate-conformational interaction (here, if $x_{m}$ exceeds its critical value $x_{m}=4$ ), acquires a twowell shape in a certain interval of $[S]$. This corresponds to bistability of the steady-state reaction regimes (in particular, to markedly different values of $b\left(x_{s}^{(1,2)}\right)$, where $x_{s}^{(1,2)}$ are positions of $V^{\text {eff }}(x)$ 's minima in the bistability window). The surface $x_{s}\left(x_{m},[S]\right)$ provides an example of a fold-type catastrophe with the projection of the fold onto plane $\left(x_{m},[S]\right)$ having the form of a wedge with a critical point at its cusp (Fig. 3). The whole picture is typical for a nonequilibrium phase transition of the $1^{\text {st }}$ kind and that of the $2^{\text {nd }}$ kind in the critical point.

Calculations of the steady-state $E S$-complex population $N_{1}^{\text {st }}([S])$ show considerably more pronounced sigmoidicity than that within the discrete schemes (see Fig. 4, a). If catalytic rate $r(x)$ is weakly dependent on $x$, then, curve $v([S])$ has the same pronouncedly 'cooperative' shape. On the other hand, specifying $r(x)$ as, for example, a Markustype rate, $r(x)=r_{0} \exp \left[-\left(\varepsilon_{r}-x\right)^{2} /\left(4 \varepsilon_{r}\right)\right]$, where $\varepsilon_{r}=E_{r} /\left(k_{B} T\right)$, and $E_{r}$ is the reorganization energy at the product release stage, one can arrive at the possibility of substrate inhibition (see Fig. 4, $b$ for an example).

Actually, the expounded considerations represent an application of our molecular self-organization concept (see [20] and references there- 

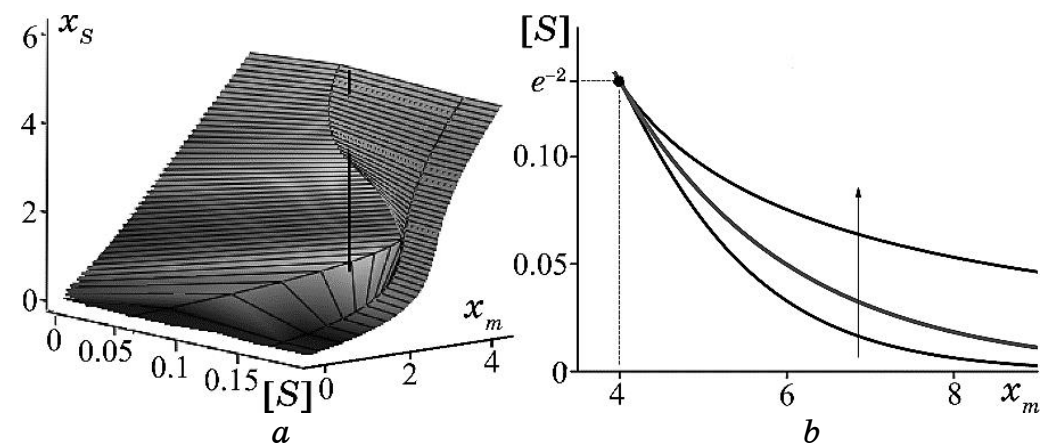

Fig. 3. Left: The surface $x_{S}$ with a fold that corresponds to the bistability area. The rod, originating from point $\left(x_{m},[S]\right)=(5.3,0.073)$ within the wedge, penetrates the fold at three points, where the middle $x_{s}$ corresponds to the unstable state. Right: Projection of the fold on plane $\left(x_{m},[S]\right)$ (a wedge with a cusp), representing the system phase diagram. At fixed $x_{m}>\mathbf{4}$ and with [S] growing, one enters and then leaves the bistability area. The middle line is an analogue of the phase coexistence curve for the $1^{\text {st }}$ kind phase transition. It ends in the critical point $\left(x_{m}^{*},\left[S^{*}\right]\right)=\left(4, e^{-2}\right)[20]$.
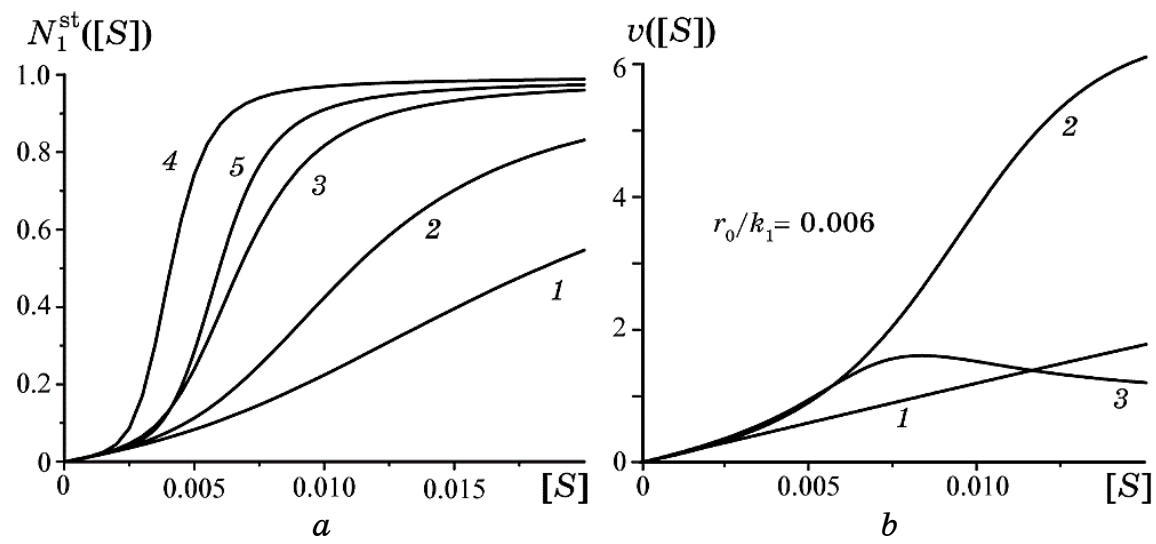

Fig. 4. Left: $(1-4)$ Dependence of the enzyme-substrate complex population on substrate concentration for different values of parameter $x_{m}=4$ (1), 5 (2), 6 (3), 7 (4). To the accuracy of factor $r$, it coincides with that of reaction velocity $v([S]) \cdot(5)$ The same for the case of $x_{m}=7$ and $x$-dependent $r(x)$ with $\varepsilon_{r}=3$, $\left.r_{0} / k_{1}=0.003\right)$. Right: Dependence of the reaction velocity on substrate concentration for different values of parameters of catalytic rate constant $r(x)$. $r_{0} / k_{1}=0.006$. (1) $\varepsilon_{r}=3, x_{m}=2 ;(2) \varepsilon_{r}=5, x_{m}=7$; (3) $\varepsilon_{r}=3, x_{m}=7$.

in) to the MM scheme. To the best of our knowledge, this concept is the first attempt of implementing synergetic phenomena at the level of molecules. 
Characteristic manifestations of the corresponding nonequilibrium phase transitions in terms typical for SM experiments are described analytically and confirmed by computer simulations [21].

\section{CONCLUDING REMARKS}

Within the discrete linear schemes, their SM versions do not lead to any principally new mechanisms and effects of conformational regulation, as compared to those within the ensemble versions. In a more adequate and natural way, such effects emerge due to the feedback between continuous conformational fluctuations and enzymatic reaction stages. Then, the enzyme functional regimes result from analogues of nonequilibrium phase transitions at the molecule level.

\section{ACKNOWLEDGEMENT}

The present work is partially supported by the Program of Fundamental Research of the Department of Physics and Astronomy of the National Academy of Sciences of Ukraine (project No. 0117U0002497).

\section{REFERENCES}

1. L. Michaelis and M. L. Menten, Biochem. Zeitschrift, 49: 333 (1913); http://dx.doi.org/10.1016/j.febslet.2013.07.015.

2. A century of Michaelis-Menten Kinetics (Eds. A. Cornish-Bowden and C. P. Whitham), FEBS Lett., 587: 2711 (2013); http://dx.doi.org/10.1016/j.febslet.2013.07.035.

3. R. Ye, X. Mao, X. Sun, and P. Chen, ACS Catal., 9: 1985 (2019); https://doi.org/10.1021/acscatal.8b04926.

4. F. Wong, A. Dutta, D. Chowdhury, and J. Gunawardena, Proc. Natl. Acad. Sci. USA, 115: 9738 (2018); https://doi.org/10.1073/pnas.1808053115.

5. H. P. Lu, L. Xun, and X. S. Xie, Science, 282: 1877 (1998); https://doi.org/10.1126/science.282.5395.1877.

6. J. Monod, J. Wyman, and J.-P. Changeaux, J. Mol. Biol., 12: 88 (1965); https://doi.org/10.1016/s0022-2836(65)80285-6.

7. B. R. Rabin, Biochem. J., 102: 22c (1967); https://doi.org/10.1042/bj1020022c.

8. S. C. Kou, B. J. Cherayil, W. Min, B. P. English, and X. S. Xie, J. Phys. Chem. $B$, 109: 19068 (2005); https://doi.org/10.1021/jp051490q.

9. B. P. English, W. Min, A. M. van Oijen, K. T. Lee, G. Luo, H. Sun, B. J. Cherayil, S. C. Kou, and X. S. Xie, Nat. Chem. Biol., 2: 87 (2006); https://doi.org/10.1038/nchembio759.

10. D. E. Piephoff, J. Wu, and J. Cao, J. Phys. Chem. Lett., 8: 3619 (2017); https://doi.org/10.1021/acs.jpclett.7b01210.

11. A. Kumar, H. Maity, and A. Dua, J. Phys. Chem. B, 119: 8490 (2015); https://doi.org/10.1021/acs.jpcb.5b03752. 
12. D. Singh and S. Chaudhury, J.Chem. Phys., 146: 145103 (2017); https://doi.org/10.1063/1.4979945.

13. D. Singh and S. Chaudhury, Chem. Phys., 523: 150 (2019); https://doi.org/10.1016/j.chemphys.2019.04.012.

14. A. M. Berezhkovskii, A. Szabo, T. Rotbart, M. Urbakh, and A. B. Kolomeisky, J.Phys. Chem. B, 121: 3437 (2017); https://doi.org/10.1021/acs.jpcb.6b09055.

15. L. N. Christophorov, Rep. Natl.Acad.Sci.Ukraine (Dopovidi), 1: 40 (2019); https://doi.org/10.15407/dopovidi2019.01.040.

16. L. N. Christophorov and V. N. Kharkyanen, Chem. Phys., 319: 330 (2005); https://doi.org/10.1016/j.chemphys.2005.06.029.

17. L. N. Christophorov, Phys. Lett. A, 205: 14 (1995); https://doi.org/10.1016/0375-9601(95)00462-c.

18. L. N. Christophorov, J. Biol. Phys., 22: 197 (1996); https://doi.org/10.1007/bf00401873.

19. L. N. Christophorov, A. R. Holzwarth, V. N. Kharkyanen, and F. van Mourik, Chem. Phys., 256: 45 (2000); https://doi.org/10.1016/s0301-0104(00)00089-6.

20. L. N. Christophorov, AIP Advances, 8: 125326 (2018); https://doi.org/10.1063/1.5055354.

21. L. N. Christophorov, V. N. Kharkyanen, and N. M. Berezetskaya, Chem. Phys. Lett., 583: 170 (2013); https://doi.org/10.1016/j.cplett.2013.08.005. 